\title{
EL CAMPESINADO ARGENTINO EN LA NOVELA DE GÜIRALDES, DON SEGUNDO SOMBRA (1926).
}

Trinidad Barrera López

Es difícil hablar del gaucho sin caer en tautologías. Pocos sujetos humanos han hecho correr tantos ríos de tinta como este campesino de la Pampa. Como ser humano conoció todas las situaciones posibles y, como ser literario, su imagen se refractó en todos los géneros. Si el negro y su problemática marcan la vida social, política y literaria del siglo XIX cubano, no menos cierto es que el gaucho hará otro tanto en la zona rioplatense, así como el indio en la zona andina. Son tres pilares básicos de la heterogeneidad humana del continente de los siete colores.

De héroe político a marginado social, de bandido a presidente gubernamental, de personaje poético a héroe dramático y/o novelesco, esta clase social irá indefectiblemente ligada a la historia de una nación, Argentina sobre todo, desde los mismos orígenes, las luchas independentistas; y protagonizará todo un siglo de la vida del país, el que se cierra prácticamente con la caída del presidente Hipólito Yrigoyen.

Si dejamos al margen la plasmación poética del gaucho en la poesía y nos atenemos a la prosa, tendríamos que trazar una línea que iría desde los testimonios de viajeros, finales del XVIII, al siglo XX, Concolorcorvo en su Lazarillo de ciegos caminantes (1773) describe a los gauderios; las noticias de Charles Darwin, publicadas en 1839, Viaje de un naturalista alrededor del mundo; pasando por las pinturas claroscuras de José Mármol en su novela Amalia (1844), o las visiblemente negras de Sarmiento en Facundo (1845), hasta desembocar en El Payador (1916) de Leopoldo Lugones, libro que marca un cambio de apreciación del gaucho que cobrará plena fuerza en Güiraldes y Lynch. «Hay que recordar - dijo Rodríguez Monegal- que antes de 1916 el gaucho no es el símbolo de la nacionalidad argentina; es más bien el símbolo de la barbarie que la nueva orgullosa nación quiso no sólo erradicar sino obliterar por el olvido» ${ }^{1}$.

1 Emir Rodríguez Monegal, «El Martín Fierro en Borges y Martínez Estrada», Revista Iberoamericana, XL, ab.-set. 64, n. 87-88, pág. 289. 
Hablar del gaucho implica hablar de la pampa, el hombre mantiene con la naturaleza, su habitat, una relación dialéctica de interdependencia que se aprecia armónica en la novela de Güiraldes que comentaremos, Don Segundo Sombra (1926). No ocurre así en otras novelas regionalistas de la misma década, La vorágine (1924), por ejemplo. Pero sobre la naturaleza de dicha relación volveremos más adelante. Ahora nos interesa marcar que la existencia de ese binomio es un estereotipo de nuestra literatura ya desde sus mismos orígenes -otro tanto ocurre con la dualidad hombre-ciudad-. Es facil notar la presencia avasalladora de la naturaleza agreste en los primeros visitantes extranjeros de aquellas tierras. Hombres de acción o cronistas improvisados se empecinan en extraer tesoros recónditos de su seno o superficie, en forma de oro, perlas, piedras preciosas o especias. Si el saqueo de la tierra marcó el espíritu de los primeros españoles en tierras americanas; el atractivo de las mismas hechizó al unísono sus mentes, iniciándose así, desde Colón, un diálogo fructífero del hombre con su entorno. Y precisamente, con el peso del tiempo, algo más de cuatro siglos, se ve en esta novela una búsqueda de las esencias profundas de esa tierra por parte de un hombre, Ricardo Güiraldes, que, aunque ciudadano europeo por adopción y perfecto conocedor de otras literaturas y lenguas - la francesa sobre todo-, no tiene empacho en autonombrarse «discípulo literario del gaucho» ${ }^{2}$. La unión del «smoking»y del «chiripá», como símbolo de la simbiosis güiraldiana ${ }^{3}$, ya estaba en aquellos pioneros nativos que, como el Inca Garcilaso de la Vega, intentan desvelar un mundo, su mundo americano, encabalgándose entre dos aristas, el viejo y el nuevo mundo, sin que ese punto desmerezca el esfuerzo de comprensión o compromiso estrecho con lo vivido y lo sentido, como sincero testimonio de autenticidad y punto de partida de los diversos modos del americanismo, a lo largo de la historia de aquel continente.

La comprensión inteligente del universo de los incas o de los campesinos gauchos responden estructuralmente a un mismo fin: señalar los pilares de una tierra plurivalente y multifacética, analizada desde la participación personal, desde el cariño y, también, desde la nostalgia (así como el Inca escribe sus Comentarios reales en su retiro cordobés, Güiraldes redacta los diez primeros capítulos en $\mathrm{Pa}-$ rís, en 1919. De vuelta a Argentina, en 1921, viajará por las provincias del norte y los campos de Dolores, que le ofrecen buen material para completarla). Claro que se puede aducir que Güiraldes entonó un canto de cisne por el gaucho, en vías de desaparición en los años veinte, pero es que el sentido nostálgico va implícito en los montajes de una utopía.

Esta novela es un buen ejemplo del programa nacionalista que se levanta hacia 1910, el cual pone en marcha una literatura neorrealista que revaloriza el folklore, las tradiciones culturales y las creencias y artes locales. «Esta generación dice Rama- hace un considerable aporte al estudio y encuadre de las literaturas latinoamericanas... porque promueve los primeros intentos razonados de pensar

2 «Carta a Valéry Larbaud», en Obras completas, Buenos Aires, Emecé, 1962, pág. 789. En adelante O.C.

3 Paul Groussac es el autor de estas metáforas, aplicadas a la crítica de esta novela. 
la producción literaria del continente con una metodología derivada de sus rasgos históricos específicos» ${ }^{4}$. No olvidemos tampoco que Güiraldes engrosó las filas de la vanguardia ultraísta argentina, uno de cuyos puntos era «amor por lo argentino», y nada más sintomático que el nombre que se utilizó para la revista portavoz de la oficialidad, Martín Fierro (1925-27).

Es fácil calificar esta novela como dignificación de la barbarie, como puente para la civilización, porque el mismo Güiraldes ha insistido, en sus escritos, en calificar al gaucho como el único tipo de auténtica humanidad surgido en su patria: «El gaucho dentro de sus medios limitados es un tipo de hombre completo. Tiene sus principios morales... tiene su filosofía casi religiosa en que admite potencias superiores encarnadas por el «destino», la «suerte» y lo «que está escrito»... También admite una ley individual, especie de destino que lleva a cada hombre por su camino especial... Tiene sus artes... Tiene su prosa, en sus cuentos de fogón (magia por lo general) y sus relatos de fuente directa, sacados de su propia vida. Tiene su poesía... sus danzas... su traje... y algo que muy pocos tienen: un estilo para moverse que implica estética, educación y respeto de sus propias

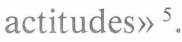

La sombra del gaucho Facundo Quiroga es demasiado alargada como para que las tesis de ambos argentinos no se complementen. Sombra está en la antípoda de Quiroga. Para la generación romántica del 30, la de los transterrados uruguayos, la pesadilla de Rosas les avocó a esos dibujos tenebrosos. Citamos la descripción de Mármol en Amalia, que, al no ser tan negra como la de su compañero Sarmiento, permite resaltar algunas de las cualidades que luego veremos en Güiraldes:

«La inmensidad, la intemperie, la soledad y los tormentos de nuestro clima meridional son las impresiones que desde su niñez comienzan a templar su espíritu y sus nervios, y a formarle la conciencia de su valor y de sus medios. Sólo, abandonado a sí mismo, aislado, por decirlo así, del trato de la sociedad civilizada, siempre en lucha con los elementos, con las necesidades y con los peligros, su espíritu se ensorberbece a medida que él triunfa de su destino... La soledad y la naturaleza han puesto en acción sobre su espíritu sus leyes invariables y eternas, y la libertad y la independencia de instintos humanos se convierten en condiciones imprescindibles de la vida del gaucho» ${ }^{6}$.

Es, sin dudas, Sarmiento el que carga las tintas en su descripción; pero, si bien él había tenido la oportunidad de comprobar los alcances nefastos de la montonera gaucha, no menos cierto es que Güiraldes, por su origen de hijo de terratenientes, había tenido también la ocasión de confirmar lo contrario, aunque, con su postura, esté más cerca de Juan Manuel Rosas que de Sarmiento —entiéndanse las diferencias ideológicas y temporales entre uno y otro-.

Pero no se trata de contrastar o de acoplar posturas, dictadas, entre otras cosas, por imperativos de épocas socio-históricas distintas, sino de afrontar la pos-

4 Angel Rama, Los gauchipolíticos rioplatenses, Buenos Aires, Calicanto, 1976, pág. 8.

5 «Notas sobre Martín Fierro y el gaucho» en O. C., ob. cit., págs. 732 y 733.

6 José Mármol, Amalia, Buenos Aires, Sopena, 1964, págs. 232-233. 
tura de Güiraldes como la de un criollismo auténtico, muy distante ya del paisajismo romántico, de los cuadros locales y arcádicos del hombre superpuesto a la naturaleza, como ocurría con Cumandá (1879), por ejemplo. Es con Don Segundo Sombra cuando el virgilianismo americano de Andrés Bello encuentra pleno desarrollo.

Los beneficios de la vida rural ya habían sido resaltados por Güiraldes con anterioridad a esta novela: Cuentos de muerte y de sangre (1915) y Raucho (1917). Del primero sobresalen, en relación con este tema, varios relatos. Uno de ellos, el que abre el libro, «Facundo», nombre de hondas evocaciones, se ha visto como antecedente del encuentro del tape Burgos con Don Segundo Sombra. Pero los ecos se advierten también en «D. Juan Manuel», «Justo José», «El remanso», «De un cuento conocido», «Trenzador», «Al rescoldo» - donde aparece el personaje de D. Segundo-y «La estancia vieja» en antítesis a «La estancia nueva». En estos breves relatos o estampas, Güiraldes pulsa los resortes más elementales de una sociedad primitiva: «la compadrada, el machismo, la fanfarronada estéril o suicida» ${ }^{7}$.

En carta a Valéry Larbaud se expresaba así nuestro hombre:

«En CMS traté de plegar mi estilo a las virtudes del hablar del gaucho que me parecían esenciales. Así traté de forzar la síntesis, hasta conseguir violencia. De haberme puesto entonces el título de un ismo me hubiera llamado esencialista» ${ }^{8}$.

En la misma línea de los Cuentos se muestra Raucho. La vida de Ricardito, entre el aquí y el allá, - Argentina/Francia-, opta finalmente por el aquí, pero no en sus formas ciudadanas, sino en sus modos campesinos. En los primeros capítulos diseña la vida de la estancia, retomando temas y personajes de los Cuentos y de su primer libro poético El cencerro de cristal (1915), pero Raucho también «nos da el boceto que Don Segundo Sombra acabará cumplidamente y en el cual el destino del hombre se enlaza, indisoluble, con el cíclico sucederse de las estaciones: los trabajos y los días» ${ }^{9}$. Las coincidencias con DSS son muchas, desde la anécdota del compañero de clase, por nombre Fabio Cáceres, el mismo del joven aprendiz de gaucho en DS, que un buen día desapareció del colegio para no volver más, circunstancia que muy bien podría coincidir con la vida que llevaba el joven, al cuidado de sus tías, al principio de la novela; hasta un nivel más general que comprendería la fuerza metafísica de los llanos. DSS ahonda la corriente centrípeta que veíamos en Raucho, porque en ambas, el espacio abierto se ha ido integrando a la identidad de Ricardito y Fabio, respectivamente, por los sentidos y por la percepción. «La apertura existencial que procura permite una integración total entre el hombre y el contorno» ${ }^{10}$.

7 Ivonne Bordelois, Genio y figura de Ricardo Güiraldes, Buenos Aires, Eudeba, 1966, pág. 56.

8 En O. C., ob. cit., pág. 789.

9 I. Bordelois, ob. cit., pág. 64.

10 Fernando Aínsa, Identidad cultural de Iberoamérica en su narrativa, Madrid, Gredos, 1986, pág. 203. 
Si Ricardo Navas cotempla a Sombra como «un Fierro purificado por el tiempo y la historia» ${ }^{11}$, es visible que el tema de lo nativo, en su dirección autóctona, como sinónimo de campesino y/o gauchesco, contaba con el precedente poético de Lugones. El autor de las Odas seculares y de El payador ya había pulsado las cuerdas de lo nacional, al poner de relieve la pureza e integridad del campo argentino. Borges ha sabido apreciarlo cuando, al comentar los logros del autor de La guerra gaucha, alude al maestro en describir los orígenes pastoriles de la sociedad argentina: «el desierto, los incendios, el regreso del padre, la yerra, los indios, los desafios de la guitarra y del cuchillo» ${ }^{12}$.

Güiraldes en El cencerro dedica las dos primeras secciones a la pampa, el gaucho y el pingo: «Chacarera», «Mi caballo» y «Al hombre que pasó» son tres composiciones donde el poeta siente honda y sinceramente el ámbito rural, como depositario de unas esencias cargadas de autenticidad. Como para López Velarde la provincia, para Güiraldes la pampa, debido a su contacto personal a través de San Antonio de Areco y la estancia La Porteña, significa el apego a las tradiciones y a sus púberes encantos. «El tipo de vida, la cultura asociada con el campo y en particular con la ganadería según la practicaba el gaucho, en un principio independientemente, y más adelante bajo la supervisión del gran terrateniente de la pampa, ha tenido un enorme impacto en la imaginación popular, afincándose, a través de la literatura y de otros medios de comunicación, como la esencia del carácter nacional» ${ }^{13}$.

Cuando Güiraldes escribe sus obras, el gaucho era el represetante nacional por excelencia, surgido gracias al sistema socioeconómico argentino, con la ganadería en primer término. Pero al mismo tiempo, con él se marca el fin de su extinción, «paralelamente — señala Rodríguez Luis - la dependencia de la prosperidad nacional de la explotación eficiente de la misma región exigía el control y transformación de la actividad económica del gaucho y, por tanto, su desaparición» ${ }^{14}$.

No olvidemos que el gaucho de Güiraldes no es, como en el caso del indio en la narrativa de aquellos años, un sujeto opositor al estanciero, su patrón; aquí no hay contraste opositivo ni lucha de clases, sino balance de fuerzas que se decantan sentimentalmente en favor del segundo, sin anular la entidad del primero. No deja de ser curioso que la tradicional subordinación obrero-patrón esté aquí invertida, siendo Cáceres - futuro patrón- el que pliega su voluntad, entre la admiración y el respeto, al resero Sombra, y cuando al final de la novela Cáceres se ve dueño de hacienda y poder exclama:

«tres años habían transcurrido desde que llegué, como un simple resero, a trocarme en patrón de mis heredades. ¡Mis heredades! Podía mirar alrededor, en

11 Ricardo Navas, «Personaje e identidad nacional: de M. F. a D. S. S.» en Saul Yurkievich, Identidad cultural de Iberoamérica en su literatura, Madrid, Alhambra, 1986, pág. 197.

12 J. L. Borges, «Leopoldo Lugones» en O. C. en colaboración, vol. II, Madrid, Alianza, 1983, pág. 42.

13 Julio Rodríguez Luis, La literatura hispanoamericana entre compromiso y experimento, Madrid, Fundamentos, 1984, pág. 36.

14 Ibídem, pág. 37. 
redondo y decirme que todo era mío. Esas palabras nada querían decir. ¿Cuándo, en mi vida de gaucho, pensé andar por campos ajenos? ¿Quién es más dueño de la pampa que un resero?» (Cap. XXVII, 494) ${ }^{15}$.

El aprendizaje físico y síquico del joven Fabio corre a cargo del símbolo gaucho Don Segundo y dura justamente hasta que el muchacho cambia de status social, momento en que Sombra hace honor a su apellido: «Se fue reduciendo como si lo cortaran de abajo en repetidos tajos» (cap. XXVII, 497).

El mérito de esta novela radica en su acercamiento al tema de lo rural gauchesco. No predica la integración del gaucho, sino su libertad, aunque paradójicamente la ejerce desde su posición de peón sedentario asalariado. Pese a que el «caminar» define su conducta, los límites del espacio que recorre son finitos. Güiraldes eleva a modelo el comportamiento humano y social que Sombra enseña, con su ejemplo, al aprendiz. El autor de Xaimaca, buen conocedor de estos predios, no se mueve solo por una cuestión de simpatía o snobismo: «al gaucho que llevo en mí sacramente, como la custodia lleva la hostia», dirá en la dedicatoria. Para hacer inteligible este mundo usará y abusará de múltiples elementos de la cultura campesina: doma, arreo, rodeo... El capítulo VIII es un auténtico muestrario de estas funciones: Cornear, enlazar, pialar, domar, correr como la gente en el rodeo, hacer riendas, bozales y cabestros, lonjear, sacar tientos, echar botones, esquilar, tusar, bolear, curar el mal del vaso, el aba, el hormiguero...

El costumbrismo está también en las fiestas y músicas de bailes, valses, polcas o mazurcas, triunfos, prados y morochas (cap. XI) o en los relatos orales, tan habituales de los campesinos (cap. XII y XXI). «La introducción de tales elementos folklóricos es resabio costumbrista, pero al mismo tiempo permite a su autor adentrarse en la poesía y la filosofía popular, adecuadas ambas al sabor de la Pampa, con su peculiar fama y las sustanciosas formas de brujería» ${ }^{16}$.

Desde el capítulo IV al XXIV, veintiuno de veintisiete capítulos están consagrados casi en su totalidad a pintar el universo campesino con todo lujo de detalles. El tiempo parece detenerse morosamente en la contemplación de las faenas domésticas. Indudablemente, en determinados momentos, llega a atosigar al lector. Por ese lado destella el costumbrismo de esta novela. Paisaje, tareas y folklore del campo van diseñando el espacio feliz, reviviendo «sui generis» el beatus ille horaciano. La armonía del hombre con la pampa es total, estamos ante un panteismo, ya visto en la poesía («Solo», El cencerro de cristal). En contacto directo con la naturaleza, parece decirnos, se puede captar el ritmo de la creación. Ese ritmo acompasado que le permite reintegrarse al pacto cósmico es símbolo de pureza y de autenticidad, imagen invertida de la relación del hombre con el tráfago ciudadano.

La tierra es madre nutricia, dadora de vida y alimento. Don Segundo, en perfecta sincronía con la madre tierra, transmite a su pupilo la enseñanza. La simbiosis es total: «A las diez el pellejo de la espalda me daba una sensación de efer-

15 Citamos por las Obras Completas de Ricardo Güiraldes, ob. cit.

16 Joaquín Marco, La literatura hispanoamericana, Madrid, Espasa Calpe, 1988, pág. 51. 
vescencia. El petiso tenía sudado el cogote. La tierra sonaba más fuerte bajo las pezuñas siempre livianas... A las once tenía hinchadas las manos y las venas. Los pies me parecían dormidos. Dolíanme el hombro y la cadera golpeados. Los novillos marchaban más pesadamente. El pulso me latía en las sienes de manera embrutecedora» (cap. VIII, 381).

Pero los valores humanos van ligados al costumbrismo. El convivir de estos hombres, y no sólo Sombra, marca un comportamiento social rotulado por la valentía, el aguante, la resistencia al dolor, a la sed, al calor, al frío, la fidelidad, el fatalismo: D. Segundo muestra «de la vida, la resistencia y la entereza en la lucha, el fatalismo en aceptar sin rezongos lo sucedido, la fuerza moral ante las aventuras sentimentales, la desconfianza ante las mujeres y la bebida, la prudencia entre los forasteros, la fe en los amigos» (cap. X, 390).

Elevar lo local al ámbito de lo universal es la tarea que se propuso Güiraldes, por eso rechaza al «gaucho» Juan Moreira: «Aquel hombre tan bien desfigurado en héroe por Gutiérrez, no tiene ni el físico ni la moral de los que quieren simbolizar... ¡Pero es que esta pobre Capital Federal está tan mal informada intencionalmente, sobre su hombre de campo!» ${ }^{17}$.

Ahora bien, si lo costumbrista y lo humano se acoplan para mostrar el símbolo argentino, no tiene cabida aquí la historia. Poco importa la historia del gaucho porque en esta novela no se trata de marcar su desarrollo, sino de plasmar un fruto donde se acopla la propensión metafísica de la literatura rioplatense, en relación estrecha — como diría Sábato- con «ese gigantesco territorio vacio, en ese paisaje desolado y abstracto» ${ }^{18}$.

Con esta novela se pone un imprescindible peldaño para la comprensión de las raíces metafísicas de la narrativa de la zona, centrada en el problema del destino del hombre, hasta el punto de que la historia literaria no puede pasar por alto su contribución. En un escritor como Sábato, pese a sus ambientes urbanos, laten constante que ya estaban en Güiraldes y en sus ambientes rurales. A uno y a otro les preocupa, sobre todo, el hombre. Ser gaucho es una dimensión moral, una categoría espiritual, emanada directamente de la tierra, un espejo donde, según Güiraldes, debería refractarse el futuro hombre argentino.

17 «Contestación a una encuesta sobre el gaucho», en O. C., ob. cit., pág. 731.

18 Ernesto Sábato, La Cultura en la encrucijada nacional, Buenos Aires, Sudamericana, 1976, pág. 96. 
